\title{
Penghalang Sosial dan Psikologis Pada Proyek Konstruksi dengan Prinsip Bangunan Hijau
}

\author{
Tri Wibowo Caesariadi \\ Program Studi Arsitektur, Universitas Tanjungpura, Indonesia \\ tricaesariadi@gmail.com
}

\begin{abstract}
ABSTRAK
Proyek konstruksi bangunan merupakan kegiatan yang menentukan penerapan prinsip bangunan hijau. Gerakan bangunan hijau yang telah berlangsung cukup lama telah cukup berhasil secara teknologi dan ekonomis, namun halangan dapat datang dari manusia yang terlibat (stakeholders) pada proyek tersebut. Penghalang ini berangkat dari faktor sosial dan psikologis manusia, yang seringkali tidak disadari. Kajian tentang penghalang tersebut dilihat dari tingkat individu, organisasi dan kelembagaan. Pemecahan masalah dilakukan dengan melihat penghalang sebagai kesempatan atau sebagai masalah yang harus dipecahkan. Faktor edukasi memegang peranan penting dalam mengubah faktor sosial dan psikologis yang menghalangi tersebut. Termasuk pula peranan penting pemerintah sebagai pengatur.
\end{abstract}

Kata kunci: bangunan hijau, proyek konstruksi, stakeholder

\begin{abstract}
Process of construction project is an activity which determines the application of the principles of green building. Green building movement has been going on for quite a while and has been significantly successful both technologically and economically. However, obstructions may come from humans involved (stakeholders) in the project. These obstructions originated from the social and psychological factors, which are often unrecognized. This study on the obstructions covered from the level of individuals, organizations and institutions. Problem solving is done by looking at the obstructions as the opportunity or as a problem to be solved. Education holds significant role in changing social and psychological factor, this includes the role of government as the regulator.
\end{abstract}

Keywords: green building, construction project, stakeholder

\section{Pendahuluan}

\subsection{Latar Belakang}

Proyek adalah pekerjaan sementara yang dilakukan untuk menciptakan/ menghasilkan produk, jasa atau hasil yang unik (PMBOK, 2008). Untuk menghasilkan produk tersebut, sebuah proyek perlu diatur secara manajerial, dikontrol dan diawasi. Hal yang perlu diatur adalah proses pekerjaan dalam proyek, termasuk manusia yang mengerjakannya.

Sebuah proyek konstruksi bangunan umumnya melibatkan banyak orang (puluhan bahkan ratusan) yang bekerja di dalamnya. Masing-masing orang dapat mempengaruhi hasil dan kelangsungan proses desain dan konstruksi serta hasil akhir. Pihak yang terlibat antara lain arsitek (bangunan dan lansekap), kontraktor, ahli teknik, konsultan energi, sub kontraktor (pondasi, plambing, listrik, HVAC, dan lainlain), produsen bahan bangunan, distributor, perangkat pemerintah, bahkan LSM serta organisasi perdagangan.

Sementara itu isu tentang lingkungan sedang menjadi topik yang hangat akhirakhir ini. Aktivis lingkungan memberikan perhatian yang besar pada lingkungan terbangun (built environment) karena dampaknya pada lingkungan. Penelitian yang telah dilakukan menunjukkan bahwa bangunan mengkonsumsi $40 \%$ bahan bangunan di dunia, menggunakan 55\% kayu untuk penggunaan di luar bahan bakar, $12,2 \%$ dari total konsumsi air, $40 \%$ dari total penggunaan listrik, menghasilkan $36 \%$ dari emisi gas karbon dioksida (Roodman, Lenssen, \& Peterson, 1995; USGBC Research Committee, 2008 dalam Hoffman \& Henn, 2008).

Karena pengaruh yang besar pada lingkungan, lahirlah gerakan bangunan hijau (green building) yang pada intinya adalah peningkatan efisiensi pada proyek 
konstruksi dalam menggunakan sumber daya dan meminimalkan dampak negatif yang dihasilkan dari proyek itu terhadap lingkungan (Retzlaff, 2009).

Gerakan bangunan hijau pada proses proyek konstruksi tentunya menuntut pelibatan aktor di dalam proses proyek tersebut. Pihak-pihak yang terlibat dalam proyek konstruksi turut bertanggung jawab pada keberhasilan proyek tersebut ditinjau dari praktek gerakan bangunan hijau.

Selama kurang lebih dua dasarwarsa pergerakannya, bangunan hijau telah mencapai banyak kemajuan. Banyak negara telah menetapkan standar bangunan hijau, yang ramah terhadap lingkungan, misalnya Leadership in Energy and Environmental Design (LEED) di Amerika Serikat atau Green Mark di Singapura. Perkembangan juga terlihat secara ekonomis. Bahan bangunan serta cara membangun yang lebih mahal (walaupun semakin lama semakin murah) dapat diganti dengan keuntungan dari kombinasi perluasan pasar produk, timbal balik pasar yang lebih besar, praktek desain terintegrasi dan biaya operasional yang lebih rendah (Hoffman \& Henn, 2008). Bahkan telah ditunjukkan pula bahwa bangunan hijau dapat meningkatkan produktivitas penggunanya.

Dengan segala kemajuan yang diperoleh gerakan bangunan hijau pada masalah teknis, ekonomis dan konstruksinya, halangan bagi bangunan hijau tetap ditemui, yaitu berupa masalah sosial dan psikologis yang ada pada manusia yang menjalankan proses proyek. Hal ini menarik untuk dicermati untuk mendapatkan cara mengatasinya.

\subsection{Permasalahan dan Tujuan}

Permasalahan kajian yang akan dibahas adalah bagaimana manusia sebagai aktor dalam proses proyek berpengaruh pada gerakan bangunan hijau. Aspek kajian adalah faktor sosial dan psikologis yang menjadi penghalang dalam proyek bangunan hijau.

Tujuan kajian adalah untuk mengetahui faktor sosial dan psikologis yang menjadi penghalang dalam proyek bangunan hijau serta cara mengatasinya.

\subsection{Lingkup Kajian}

Lingkup kajian adalah hanya meliputi aspek sosial dan psikologis yang diperkirakan mempengaruhi manusia sebagai aktor dalam proses proyek yang mendukung gerakan bangunan hijau.

\subsection{Metode Kajian}

Metode kajian yang digunakan adalah metode deskripsi eksploratif sumber literatur. Bahan kajian utama adalah makalah dari Andrew J. Hoffman dan Rebecca Henn, yaitu Overcoming the Social and Psychological Barriers to Green Building (2008) yang kemudian dielaborasikan dengan kondisi proyek konstruksi secara umum di Indonesia.

\section{Proyek dan Bangunan Hijau \\ 2.1 Pengertian Proyek}

Menurut PMBOK (2008), proyek adalah pekerjaan sementara yang dilakukan untuk menciptakan/menghasil-kan produk, jasa atau hasil yang unik. Sementara berarti sebuah proyek mempunyai batas waktu atau tidak selamanya berlangsung, atau dengan kata lain setiap proyek mempunyai awal dan akhir yang jelas. Unik berarti khas, berbeda dengan lainnya. Walaupun kegiatan dalam proyek dapat dilakukan berulang-ulang, perbedaan pemilik, desain, lokasi, kontraktor, dan lain-lain, membuat setiap proyek berbeda antara satu dengan lainnya. Sebuah proyek dapat melibatkan hanya satu orang, organisasi satu unit atau organisasi multi-unit.

Hasil yang dapat diproduksi sebuah proyek adalah:

- Produk atau artifak, hasil akhir atau bagian dari produk yang lebih besar

- Kemampuan untuk melakukan layanan jasa

- Hasil, seperti keluaran atau dokumen.

\subsection{Pelaku Proyek (Stakeholders)}

Pelaku proyek atau stakeholders adalah orang atau organisasi yang secara aktif terlibat pada proyek atau yang kepentingannya dapat dipengaruhi (baik secara positif atau negatif) oleh performa atau penyelesaian proyek (PMBOK, 2008).

Manajer proyek harus dapat mengidentifikasi siapa-siapa saja yang terlibat atau terpengaruh oleh proyek untuk mendapatkan persyaratan proyek dan apa yang diharapkan dari pihak yang terlibat. 


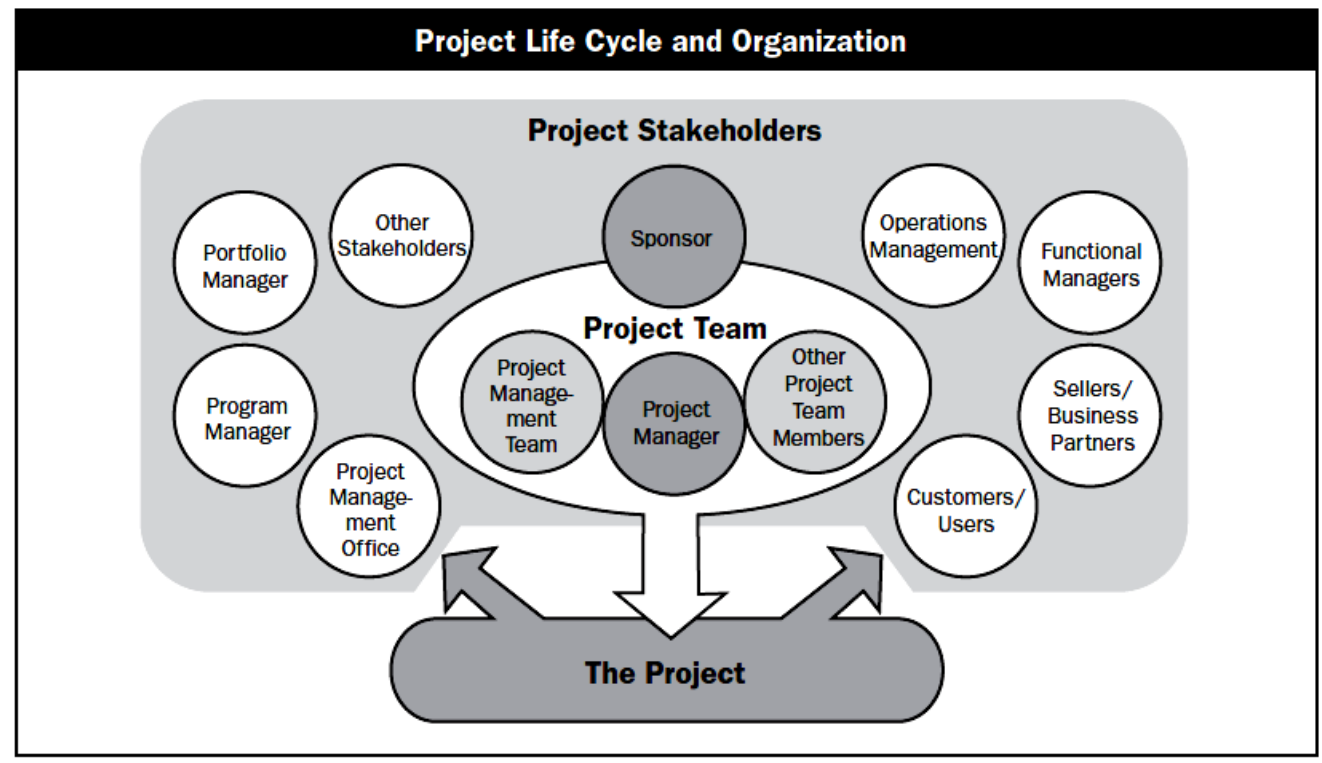

Gambar 1: Hubungan antara pelaku proyek dan proyek Sumber: PMBOK, 2008

Pihak yang terlibat dalam sebuah proyek konstruksi bangunan antara lain adalah arsitek (bangunan dan lansekap), kontraktor, ahli teknik, konsultan energi, sub kontraktor (pondasi, plambing, listrik, HVAC, dan lain-lain), produsen bahan bangunan, distributor, perangkat pemerintah, bahkan LSM serta organisasi perdagangan (Hoffman \& Henn, 2008).

\subsection{Gerakan Bangunan Hijau (Green Building)}

"Bangunan hijau" adalah struktur atau kumpulan struktur yang dirancang untuk meningkatkan efisiensi dalam penggunaan sumber daya, termasuk energi, air, kualitas udara ruang dalam, penggunaan lahan (siting), infrastruktur dan polusi (Retzlaff, 2009). Istilah bangunan hijau berarti penggunaan strategi, teknik dan produk konstruksi yang menggunakan sumber daya lebih sedikit atau menghasilkan polusi lebih kecil daripada konstruksi biasa (Hoffman \& Henn, 2008).

Pengertian tersebut menunjukkan bahwa bangunan hijau dilihat tidak hanya sebagai sebuah produk jadi, namun keseluruhan proses untuk merencanakan dan membangun bangunan tersebut. Misalnya menggunakan bahan bangunan yang lebih tidak beracun, menerapkan strategi yang lebih baik dalam memanfaatkan potensi tapak atau memanfaatkan parameter desain yang lebih baik dalam pemanfaatan energi yang lebih efisien.
Selama kurang lebih dua dasarwarsa pergerakannya, bangunan hijau telah mencapai banyak kemajuan. Amerika Serikat memperkenalkan sistem penilaian bangunan berdasarkan dampaknya terhadap lingkungan, yaitu Leadership in Energy and Environmental Design (LEED) yang kemudian diikuti oleh negara-negara lain. Hal tersebut mendorong bidangbidang yang berkaitan dengan bangunan turut serta mengkampanyekan bangunan hijau pada produk mereka. Contohnya banyak bahan cat non VOC (volatile organic compounds) yang dikembangkan, toilet dengan sistem penyiraman ganda (dual flush) telah diproduksi oleh produsen besar, penggunaan atap hijau yang semakin banyak, dan lain-lain.

Secara ekonomis, gerakan bangunan hijau juga telah berkembang. Bahan bangunan serta cara membangun yang lebih mahal (walaupun semakin lama semakin murah) dapat diganti dengan keuntungan dari kombinasi perluasan pasar produk, timbal balik pasar yang lebih besar, praktek desain terintegrasi dan biaya operasional yang lebih rendah (Hoffman \& Henn, 2008). Bahkan telah ditunjukkan pula bahwa bangunan hijau dapat meningkatkan produktivitas penggunanya.

\section{Penghalang Perilaku pada Bangunan Hijau \\ Dengan segala kemajuan yang}


diperoleh gerakan bangunan hijau pada masalah teknis, ekonomis dan konstruksinya, halangan bagi bangunan hijau tetap ditemui, yaitu berupa masalah kognitif dan sosial. Penghalang ini terdapat pada tingkat individual, organisasi dan kelembagaan (institusional).

\subsection{Perspektif di Tingkat Individual}

Para peneliti di bidang sosiologi, psikologi, antropologi dan ilmu politik menemukan bahwa orang seringkali melakukan keputusan yang bias secara sistematis dan dapat diprediksi, namun umumnya tidak disadari oleh orang tersebut (Hoffman \& Henn, 2008). Bias tersebut dapat berpengaruh pada gerakan bangunan hijau dan dapat dilihat secara khusus pada:

a. Egosentrisme

Penelitian menunjukkan bahwa dalam menghasilkan penilaian yang adil, orang cenderung memikirkan diri sendiri, atau egosentris, dan mempunyai penilaian sendiri-sendiri tentang adil. Hal ini menunjukkan bahwa penilaian seseorang yang dianggapnya baik atau adil mungkin tidak sejalan dengan lingkungan yang lestari (sustainable environment).

b. Ilusi positif

Masih berhubungan dengan egosentris, ilusi positif mengacu pada kecenderungan manusia melihat dirinya, masa depannya dan dunia dalam keadaan yang lebih baik. Banyak orang sebenarnya tidak melakukan lebih untuk lingkungan karena merasa sudah berlaku baik pada lingkungan.

c. Dugaan hubungan (presumed association)

Orang cenderung untuk menghubungkan dan menilai dua kejadian walaupun penilaian tersebut belum tentu tepat. Misalnya orang selalu menghubungkan bangunan hijau dengan ketidaknyamanan dan tidak estetis.

d. Literatur lingkungan

Kekurangan literatur tentang lingkungan turut mendukung keputusan yang bias. Penelitian di Amerika oleh Kempton et al. pada tahun 1995 (dalam Hoffman \& Henn, 2008) menunjukkan bahwa masyarakat menganggap perubahan rata-rata temperatur global sebesar $1,5^{\circ} \mathrm{C}-5^{\circ} \mathrm{C}$ Langkau Betang: Vol. 2, No.1 (ISSN 2355-2484) bukan merupakan masalah sementara para ahli memperkirakan perubahan sebanyak $1^{\circ} \mathrm{C}$ saja dapat menimbulkan efek global. Kekurangan literatur ini membuat masyarakat sulit untuk melihat hubungan antara penghematan energi dengan perubahan iklim dan mengurangi pemahaman tentang pentingnya isu-isu lingkungan, apalagi tentang bangunan hijau.

\subsection{Perspektif di Tingkat Organisasi}

Organisasi yang dimaksud di sini adalah kumpulan individu yang berelaborasi dalam proses proyek pembangunan. Organisasi dapat menjadi penyaring bagi individu dalam melihat dunia luar, bagaimana informasi luar dikembangkan, diartikan, disebarkan dan disikapi (March, 1981 dalam Hoffman \& Henn, 2008). Budaya organisasi akan membentuk persepsi serta perilaku anggotanya. Sebuah proyek konstruksi dapat dilihat sebagai sebuah organisasi sementara (temporer), kumpulan dari banyak orang yang terlibat di dalamnya. Pikiran dan sikap individual dalam organisasi dapat ditentukan oleh (Hoffman \& Henn, 2008):

a. Struktur

Struktur sebuah organisasi menentukan batasan, aturan berinteraksi dan pembagian tanggung jawab. Struktur juga menentukan jalannya informasi yang mengalir dalam organisasi, yang belum tentu efisien.

Dalam proses perancangan dan konstruksi sebuah bangunan akan terbentuk organisasi sementara (temporer), yang terdiri di dalamnya terlibat pemilik, arsitek, kontraktor, konsultan dan ahli teknik lainnya. Dalam waktu yang temporer ini, akan terbentuk budaya organisasi. Bermacam kepentingan yang ada dalam struktur organisasi tersebut dapat menjadi halangan bagi kelancaran proses. Ketika "hijau" ditambahkan dalam sebuah proyek konstruksi bangunan, peranan dan hubungan antar anggota mungkin perlu disusun ulang agar dapat menyesuaikan dengan baik.

Dalam konteks bangunan hijau, kegiatan yang dilakukan dalam proyek harus dilakukan dengan cepat dan dengan cara yang lebih terintegrasi

Hal 89 
serta kolaborasi yang lebih baik. Hal ini menuntut cara berpikir yang baru dan tiap anggota dituntut untuk menyesuaikan parameter desain yang mungkin belum pernah dilakukan sebelumnya.

b. Bahasa dan terminologi

Teknologi baru yang berkembang karena gerakan bangunan hijau menghasilkan banyak istilah baru dalam proyek konstruksi. Atap hijau, photovoltaic, turbin angin, merupakan sebagian dari istilah-istilah tersebut. $\mathrm{Hal}$ ini dapat menjadi masalah bagi pihak yang tidak terbiasa, apalagi tidak mau mengetahui istilah baru tersebut.

c. Kelembaman (inertia) organisasi

Umumnya organisasi tidak suka untuk berubah, orang di dalamnya lebih memilih melakukan kegiatan rutin yang telah dilakukan berulang-ulang dan pasti. Hal ini dapat disebabkan beberapa hal, antara lain:

1) Kebiasaan rutin yang dipertahankan walaupun diketahui dapat merusak lingkungan atau tidak efektif dan efisien. Kebiasaan rutin ini bisa saja tidak disadari. Misalnya memotong kertas gambar dengan cara yang tidak efisien hanya karena mudah dilakukan.

2) Ketakutan pada yang tidak diketahui dapat menimbulkan kelembaman organisasi maupun asumsi yang melatarbelakanginya. Perubahan dapat mempengaruhi anggota organisasi, apalagi jika hasil perubahan tersebut tidak dapat diketahui atau diprediksi. Resiko menerapkan teknologi baru pada proyek konstruksi akan lebih besar.

3) Keterbatasan sumber daya dapat membatasi kemampuan organisasi untuk memecahkan masalah, terutama yang berhubungan dengan dana. Pembuat keputusan cenderung melihat kebutuhan jangka pendek daripada keuntungan jangka panjang.

\subsection{Perspektif di Tingkat Kelembagaan (Institusional)}

Kelembagaan di sini dimaksudkan sebagai hal-hal di luar organisasi, di tingkat yang lebih luas, yang akan mempengaruhi bagaimana organisasi tersebut bekerja. Hal Langkau Betang: Vol. 2, No.1 (ISSN 2355-2484) ini mencakup batasan teknis seperti sumber daya alam, ketenagakerjaan dan pengaruh sosial yang diwujudkan dalam peraturan, hukum, standar industri, praktek yang telah terbukti dan kebijakan konvensional (Hoffman \& Henn, 2008). Kelembagaan memperlihatkan budaya dan batasan kontekstual yang dapat mengubah cara panda individu dan organisasi.

Kelembagaan dapat berpengaruh pada praktek konstruksi hijau, ditinjau dari aspek (Hoffman \& Henn, 2008):

a. Regulatif

Yaitu yang berhubungan dengan hukum dan diterjemahkan dalam bentuk peraturan. Peraturan, walaupun terbukti merupakan hal yang baik, dapat melupakan rasionalitas, inovasi dan kepekaan sosial. Hal-hal yang mungkin lebih baik bisa tidak diterima karena di luar standar.

Misalnya dengan telah adanya standar bagi bangunan rumah sakit, teknologi atau sistem manajemen baru yang ditemukan mungkin tidak diterima karena tidak sesuai dengan standar rumah sakit yang telah ada, walaupun sistem tersebut lebih baik.

b. Normatif

Tingkat normatif terletak pada kurikulum pendidikan, aturan praktis di bisnis, standar prosedur operasional dan indikator ekonomi dan bisnis. Industri bangunan biasanya telah memiliki standar yang telah dibuat oleh berbagai organisasi. Di Amerika Serikat terdapat American Society of Heating, Refrigerating and Air Conditioning Engineers (ASHRAE), The American National Standards Institute (ANSI), dan lainnya. Di Indonesia kita mengenal di antaranya Standar Nasional Indonesia (SNI). Namun penambahan materi berkaitan dengan bangunan hijau pada standar ini sangat lambat.

Contoh di Amerika Serikat, walaupun produsen semen dapat mereduksi emisi $\mathrm{CO}_{2}$ per ton semen dengan menambah komponen mineral pada semennya, asosiasi industri semen di sana menolak hal ini. Terlebih lagi para ahli struktur lebih yakin menggunakan semen dengan standar yang dikeluarkan asosiasi (yang telah digunakan bertahun-tahun) walaupun telah ada standar baru (dan kurang dikenal) yang sebenarnya juga memenuhi syarat.

Hal 90 
c. Kognitif

Tingkat kognitif yang dimaksud adalah aspek budaya yang terbangun berdasarkan penerimaan sosial masyarakat. Pada tingkat ini persepsi umum yang tercipta lebih tidak disadari, sehingga masalah yang ada pun menjadi tidak dipersoalkan (Zucker, 1983 dalam Hoffman \& Henn, 2008). Sebagian besar bentuk pembangunan lingkungan binaan - rumah, kantor, dan lain-lain - didukung oleh kelembagaan kognitif ini.

Contoh dari hal ini antara lain adalah di Amerika Serikat terdapat konsep bahwa rumah harus memiliki halaman hijau, walaupun rumah tersebut terletak di padang pasir; atau harus memiliki garasi, walaupun terletak di daerah perkotaan padat. Contoh di Indonesia adalah bahwa tempat tinggal bagi kita adalah rumah di atas tanah, lengkap dengan lahannya. Hal ini membuat masyarakat kita sulit menerima mempunyai tempat tinggal di gedung bertingkat (rusun, flat, apartemen). Padahal salah satu gerakan bangunan hijau mendorong manusia untuk bertempat tinggal di bangunan yang kompak (bertingkat) di kota sehingga dapat mengurangi beban transportasi kota untuk mobilisasi dari tempat tinggal ke tempat kerja.

\section{Mengatasi Penghalang Gerakan Bangunan Hijau}

Untuk mengatasi penghalang gerakan bangunan hijau secara sosial dan psikologis seperti yang telah dipaparkan, Hoffman dan Henn (2008) mengusulkan dua kategori menyelesaikan masalah: (a) memperlakukan penghalang sebagai kesempatan atau (b) memperlakukannya sebagai hal yang harus diatasi. Baik cara pertama atau kedua tidak dapat diterapkan sendiri-sendiri pada tingkat individual, organisasi atau kelembagaan; namun diselesaikan dengan saling berhubungan di semua tingkat.

\subsection{Penghalang Sosial dan Psikologis sebagai Kesempatan}

Keuntungan-keuntungan yang didapat dari gerakan bangunan hijau dapat digunakan untuk mendapatkannya secara optimal dari segi finansial. Misalnya memberikan apresiasi tinggi pada bangunLangkau Betang: Vol. 2, No.1 (ISSN 2355-2484) an bersertifikasi hijau dengan menaikkan harga jual atau sewa. Hijau menjadi faktor yang memberikan nilai tambah bagi bangunan tersebut.

Beberapa bank dan lembaga keuangan lain di Amerika Serikat telah mulai menawarkan pinjaman berbasis bangunan hijau. Misalnya memberikan pinjaman dan potongan yang lebih besar pada masyarakat yang hendak membeli rumah dengan kualifikasi Energy Star (Hoffman \& Henn, 2008). Hal ini dapat diterapkan di Indonesia, namun sebelumnya perlu diterapkan sistem penilaian bangunan berdasarkan prinsip bangunan hijau. Sistem penilaian ini telah dikembangkan oleh Green Building Council Indonesia sejak tahun 2009, namun sampai saat ini belum diterapkan secara penuh. Sistem ini diperlukan sebagai standar yang menentukan nilai dampak sebuah bangunan terhadap lingkungan.

\subsection{Penghalang Sosial dan Psikologis sebagai Masalah yang Harus Diselesaikan}

Tiga tahap pemecahan masalah seperti yang diusulkan Lewin (1947) dalam Hoffman \& Henn (2008) dapat digunakan untuk memecahkan masalah penghalang sosial dan psikologis pada bangunan hijau. Tahap tersebut dimulai dengan proses mencairkan pemikiran, menyiapkan masyarakat untuk perubahan. Kemudian proses perubahan itu sendiri, seseorang (yang telah dicairkan) mau untuk menerima perubahan serta akibat yang ditimbulkan. Tahap ketiga, agar perubahan tadi tidak berubah kembali ke posisi awal, adalah memperkuat perubahan tadi dan membekukan kembali.

Proses mencairkan pola pikir adalah kunci dari keberhasilan perubahan ini karena jika dapat dicairkan, maka individu, organisasi atau kelembagaan dapat menerima perubahan perilaku dan konsep bangunan hijau. Untuk proses pencairan ini dapat dilakukan tujuh strategi, yaitu:

1. Framing, pembentukan pola pikir baru. Hal baru akan lebih diterima jika ditampilkan sebagai pilihan yang menarik dan positif dibandingkan sebagai sebuah pengorbanan (HowardGrenville \& Hoffman, 2003 dalam Hoffman \& Henn, 2008). Hal ini dapat disampaikan baik secara ekonomi, spiritual, kesehatan atau teknologi. Hal 91 
Misalnya, pemakaian teknologi baru dalam membangun dikaitkan dengan pemakaian istilah "bangunan pintar" atau "bangunan performa tinggi" dibandingkan "bangunan hijau"; penerapan sistem konstruksi yang baru dapat menghemat waktu, mem-berikan rasa aman dan lebih mudah; dan lain sebagainya.

2. Menargetkan sasaran. Untuk mendapatkan penerimaan yang baik, harus diketahui sasaran yang tepat, yang lebih dapat dan mau mengambil resiko dari konsep bangunan hijau. Asosiasi profesi dan konsultan dapat dipilih karena pengaruhnya juga besar pada pelaku industri konstruksi.

3. Pendidikan. Para pelaku industri konstruksi sangat dipengaruhi oleh nilai dan aturan yang diterimanya pada tahap pendidikan sebelumnya. Untuk itu, salah satu cara menyelesaikan masalah sosial adalah dengan mengintegrasikan pengetahuan tentang lingkungan pada sistem pelatihan yang telah ada. Termasuk di dalamnya adalah kurikulum di pendidikan menengah kejuruan (SMK bangunan/ konstruksi), pendidikan tinggi bagi arsitek dan ahli teknik, pelatihan bagi karyawan magang, dan bahkan pendidikan praktis bagi para pemilik dan manajer.

4. Perubahan pada struktur pekerjaan dan pemberian insentif. Tim yang terlibat dalam konstruksi harus dapat mengintegrasikan pendekatan isu bangunan hijau dalam proses kerja mereka secara struktural. Lebih jauh lagi diperlukan perubahan pada kontrak yang umum digunakan saat ini. Kontrak antara pemilik, arsitek dan kontraktor seharusnya berisi persetujuan untuk bersama-sama menanggung semua resiko dan penghargaan tentang hal yang telah disepakati berkaitan dengan bangunan hijau.

5. Mengganti rugi resiko. Bangunan hijau memerlukan teknologi baru, resiko baru, dan mungkin saja sub kontraktor khawatir bahwa resiko pengerjaannya akan ditimpakan pada mereka. Untuk itu dapat ditawarkan pada mereka bentuk ganti rugi tertentu jika terjadi kegagalan teknologi.

6. Standar untuk bangunan hijau. Standar yang sudah ada harus selalu diLangkau Betang: Vol. 2, No.1 (ISSN 2355-2484) kembangkan karena bidang ini juga selalu berkembang. Standar yang baik harus mempromosikan bangunan hijau sebagai proses yang holistik dan akurat dalam mengurangi dampak bangunan bagi lingkungan.

7. Pengembalian pajak. Pemerintah dapat berperan, misalnya dengan memberikan insentif pajak (memberikan pajak yang kecil) pada proyek yang memenuhi syarat bangunan hijau.

\section{Kesimpulan}

Proses proyek yang menerapkan prinsip bangunan hijau sudah seharusnya selalu diterapkan di setiap proyek konstruksi. Namun penerapan prinsip ini bisa saja gagal bukan karena bukan faktor teknis dan ekonomis, namun karena faktor manusia di dalamnya,. Secara sosial dan psikologis terdapat hal-hal yang menghalangi penerapan prinsip bangunan hijau.

Hal-hal yang menghalangi pada tingkat individu dan organisasi dapat dipecahkan dengan memberikan edukasi dan pengertian yang lebih baik tentang bangunan hijau, sehingga mitos-mitos yang ada selama ini dapat diperjelas benar tidaknya. Pada tingkat kelembagaan, diperlukan keikutsertaan semua pihak untuk dapat memecahkan masalah penghalang tadi secara bersama-sama.

Edukasi yang lebih baik dapat dilakukan dengan penerapan kurikulum di lembaga edukasi dari tingkat sekolah dasar sampai perguruan tinggi. Kesadaran kognitif yang diberikan sejak masih muda diharapkan dapat menjadi bekal yang baik untuk tujuan jangka panjang penerapan prinsip bangunan hijau ini.

Peran pemerintah sepertinya merupakan sesuatu yang penting dalam menerapkan prinsip bangunan hijau di semua proyek konstruksi. Hal yang mutlak dilakukan adalah membuat standar sistem penilaian yang dapat diterapkan di semua tingkat proyek konstruksi di Indonesia. Dengan demikian dapat dengan diketahui parameter yang menentukan nilai "hijau" sebuah proyek konstruksi. Baru setelah itu prinsip bangunan hijau dapat diterapkan secara utuh di Indonesia.

\section{Daftar Pustaka}

2008. A Guide to the Project Management Body of Knowledge (PMBOK® Guide) - Fourth Edition.

Hal 92 
Newtown Square: Project Management Institute.

Indonesia.

Green Building Council http://www.gbcindonesia.org. Akses: 7 Desember 2010.

Hoffman, Andrew J. \& Henn, Rebecca. 2008. Overcoming the Social and Psychological Barriers to Green Building. Organization and Environment, Vol. 21 number 4, December 2008. Sage Publications. http://oae.sagepub.com/content/21/4/ 390.refs.html

Retzlaff, Rebecca C. 2009. The Use of LEED in Planning and Development Regulation: An Exploratory Analysis. Journal of Planning Education and Research, Vol. 29, May 2009. Sage Publications. http://jpe.sagepub.com/ content/ 29/1/67.refs.html 